\title{
Natural Diet of Callinectes ornatus Ordway, 1863 (Decapoda, Portunidae) in the Itapocoroy Inlet, Penha, SC, Brazil
}

\author{
Joaquim Olinto Branco ${ }^{*}$; Maria José Lunardon-Branco ${ }^{1,2}$; José Roberto Verani $^{2}$; Rodrigo \\ Schveitzer $^{1}$; Flávio Xavier Souto ${ }^{1}$ and William Guimarães Vale ${ }^{1}$ \\ ${ }^{1}$ Centro de Ciências Tecnológicas, da Terra e do Mar-CTTMar, Universidade do Vale do Itajaí. Caixa Postal 360 , \\ 88301-970 Itajaí - SC, Brazil; ${ }^{2}$ Universidade Federal de São Carlos - PPG-ERN, Via Washington Luiz, km 235 C. \\ Postal 676, CEP 13565 - 905 São Carlos - SP, Brazil.
}

\begin{abstract}
From January to December 1995, 332 individuals of the Callinectes ornatus species were collected from the Itapocoroy inlet in Penha, Sta. Catarina, Brazil to study its natural diet and the seasonal variations of diet. Results showed a diversified trophic spectrum with a generalized dietary strategy comprising the algae, macrophyta, foraminiferida, mollusca, polychaeta, crustacea, echinodermata, Osteichthyes and NIOM (Nonidentified Organic Matter) groups.
\end{abstract}

Key words: C. ornatus, Portunidae, natural diet, dietary habits, dietary ecology

\section{INTRODUCTION}

Callinectes ornatus Ordway, 1863, which is present in the west Atlantic from North Carolina, USA to Rio Grande do Sul, Brazil can be found at depths of up to 75 meters in sand and mud bottoms, as well as in waters with lower salt content (Melo, 1996). In addition to being a saprophagous species, it is also a predator that digs into the substrate in search of food and participates in the diet of other aquatic organisms (Haefner, 1990; Nonato et al., 1990). The available literature on the species covers the aspects of distribution, occurrence, reproduction, morphology (Gore, 1977; Norse, 1978; Paul, 1982; Branco \& Lunardon-Branco, 1993 a, b; Melo, 1996) And Diet (Williams, 1981; Haefner, 1990; Nonato e al., 1990; Moncada \& Gomes, 1980; Stoner \& Buchanan, 1990). The purpose of this work was to study the natural diet of $C$. ornatus and the seasonal variations of the diet of the population of the Itapocoroy inlet in the municipality of Penha, $\mathrm{SC}$, Brazil.

\section{MATERIALS AND METHODS}

The samples were collected monthly, from January through December 1995, in the Itapocoroy inlet at a depth varying from 5 to 10 meters using a overtrawl net with doors. The average sampling time was 30 minutes and speed was two knots. The samples were placed in a styrofoam container on ice and were laboratory processed immediately after disembarkation. Identification and recognition of sex was done according to Williams (1974), and determination of the state of maturity (young/adult) according to the shape and adherence of the abdomen to the thoracic sternum by Taissoum method (1969), using a stereoscopic microscope whenever necessary. The width of the

Author for correspondence 
carapace (between the ends of the side spikes) and the total weight (in grams) of each sample were measured.

Identification of dietary items was done according to Rios, 1975; Nonato \& Amaral, 1979; Amaral \& Nonato, 1981; 1982; Barnes, 1984; Elner đ al., 1985; And Nonato et al., 1990. Items that were unidentifiable due to their advanced state of digestion were considered Nonidentified Organic Matter (NIOM). The dietary items were divided into nine groups: 1) Algae, 2) Macrophyta, 3) Foraminiferida, 4) Mollusca, 5) Polychaeta, 6) Crustacea, 7) Echinodermata, 8) Osteichthyes, and 9) NIOM. Sand was not considered a trophic category since it does not provide information about the nature of the diet (Williams, 1982). The trophic categories were analysed qualitatively and quantitatively using Hynes (1950) and Williams (1981) methods of frequency of occurrence (FO), of points (MP). For comparison and a better comprehension of the importance of each trophic category, the feeding index (IAi) was used as proposed by Kawakami \& Vazzoler (1980) that combines both methods.

\section{RESULTS AND DISCUSSION}

Three hundred and thirty-two specimens were collected from the Itapocoroy inlet (209 males and 123 females) from January through December 1995 (Table 1). The total body length of these varied from 2.2 to $10.5 \mathrm{~cm}$. Stomachs with contents were more frequent in the case of both males $(53.1 \%)$ and females $(63.4 \%)$ (Table 1). Results of Table 2 reveal that the Osteichthyes $(22.41 \%)$ contributed with the highest relative volume in points, followed by the non-identified Brachyura (15.19\%), Penaeidae (14.75\%) and Bivalvia (8.36\%). However, in terms of frequency of occurrence, small variations were observed among the specimens investigated: Osteichthyes (13.28\%), Bivalvia (11.11\%), non-identified Brachyura (10.84\%) and Penaeidae (9.21\%). C. ornatus presented a diversified trophic spectrum at several levels. Crustacea represented the highest diversity of their prey, the non-identified Brachyura, followed by Penaeidae and species of the Callinectes. Among the Mollusca, the most representative item was Bivalvia, while among the
Annelida, non-identified Polychaeta were the most frequent and among the Echinodermata, it was the Ophiuroidea that most contributed in terms of relative volume and frequency of occurrence. Haefner's (1990) findings from Mullet Bay (Bermudas) were similar for C. ornatus, however, the most important item was Mollusca, which could be justified by its abundance in that region. The lack of inventories of the marine fauna in the Itapocoroy inlet precluded us from reporting on the abundance of these groups in the region. Nonetheless, our findings indicated that among the invertebrates found in the diet of $C$. ornatus, Bivalvia were the most frequent, although nonidentified Brachyura were the most abundant. Moncada \& Gómez (1980), characterized $C$. ornatus as a predator of the species of the Penaeus. This was related to the pattern of distribution of the species of the Callinectes and the Penaeus (Williams, 1974 apud Moncada \& Gómez, 1980). The main items in the diet were vegetable and crustacean remains. It has proved difficult to identify the Mollusca, as well as other dietary items of C. ornatus (Moncada \& Gómez, 1980; Haefner, 1990), owing to the species' strategy of fragmenting the larger individuals it captures in order to ingest them. On the other hand, the small individuals are ingested practically intact, which allows for their identification. Although sand occupied $9.08 \%$ of the stomach volume and was found in $26.02 \%$ of the stomachs, it was not considered an trophic item or category. These percentages could be justified by the behavior of the species which, when manipulating its diet, ingested a certain amount of sand with it. Branco (1996) stated that the large amount of sand ingested by the $C$. danae species was probably related to the ingestion of its prey. Haefner (1990) considered it difficult to correctly evaluate the value of the nonidentified organic matter, sand and sediment, believing it will not continue posing a problem in studies of natural diets. Indeed, in Mullet Bay, he observed C. ornatus taking sediment into its mouth together with the chelipeds, stomach volume and was present in $3.28 \%$ of the stomachs analyzed. Branco (1996) found NIOM to be the item most consumed by adult individuals of $C$. danae in the Lagoa da Conceição, state of Santa Catarina, Brazil. 
Table 1 - Callinectes ornatus. Frequency of occurrence distribution of males and females with contents and empty stomachs, in the period from January to December/95.

\begin{tabular}{cccccc}
\hline & & \multicolumn{2}{c}{ Stomachs } & \multicolumn{2}{c}{ With Contents } \\
\hline Sex & $\mathrm{N}$ & $\%$ & $\mathrm{~N}$ & $\%$ & Total \\
\hline Males & 98 & 26.9 & 111 & 53.1 & 209 \\
Females & 45 & 36.6 & 78 & 63.4 & 123 \\
\hline Total & 143 & 43.07 & 189 & 56.93 & 332 \\
\hline
\end{tabular}

Table 2 - Callinectes ornatus. Frequency of occurrence (FO) and points (MP) of the feeding items in stomachs contents, for grouped sexes, during the study period.

\begin{tabular}{|c|c|c|c|c|}
\hline Itens & MP & $\%$ & $\mathrm{FO}$ & $\%$ \\
\hline Algae & 396 & 3.96 & 12 & 3.28 \\
\hline Macrophyta & 30 & 0.30 & 1 & 0.27 \\
\hline \multicolumn{5}{|l|}{ PROTOZOA } \\
\hline Foraminiferida & 2 & 0.02 & 1 & 0.27 \\
\hline \multicolumn{5}{|l|}{ MOLLUSCA } \\
\hline Bivalvia & 835 & 8.36 & 41 & 11.20 \\
\hline Gastropoda & 137 & 1.37 & 5 & 1.37 \\
\hline $\begin{array}{l}\text { Cephalopoda/Loligonidae } \\
\text { ANNELIDA/POLYCHAETA }\end{array}$ & 185 & 1.85 & 3 & 0.82 \\
\hline Polynoidae & 2 & 0.02 & 1 & 0.27 \\
\hline $\begin{array}{l}\text { Polychaeta not identified } \\
\text { CRUSTACEA }\end{array}$ & \multicolumn{3}{|c|}{ CRUSTACEA } & 3.82 \\
\hline Mysidacea & 152 & 1.52 & 3 & 0.82 \\
\hline General Amphipoda & 18 & 0.18 & 5 & 1.37 \\
\hline Gammaridae & 97 & 0.97 & 5 & 1.37 \\
\hline Isopoda & 12 & 0.12 & 2 & 0.55 \\
\hline Decapoda not identified & 190 & 1.90 & 5 & 1.37 \\
\hline Penaeidae & 1473 & 14.75 & 34 & 9.29 \\
\hline Farfantepenaeus paulensis & 50 & 0.50 & 1 & 0.27 \\
\hline \multicolumn{5}{|l|}{ Sergestidae } \\
\hline \multicolumn{5}{|l|}{ Portunidae } \\
\hline Callinectes spp. & 524 & 5.25 & 14 & 3.82 \\
\hline Xanthidae & 25 & 0.25 & 1 & 0.27 \\
\hline \multicolumn{5}{|l|}{ Anomura/Diogenidae } \\
\hline Dardanus insignis & 75 & 0.75 & 1 & 0.27 \\
\hline Crustacea eggs & 4 & 0.04 & 2 & 0.55 \\
\hline \multicolumn{5}{|l|}{ ECHINODERMATA } \\
\hline Ophiuroidea & 255 & 2.55 & 15 & 4.10 \\
\hline Echinodermata not identified & 2 & 0.02 & 1 & 0.27 \\
\hline Osteichthyes & 2239 & 22.41 & 49 & 13.40 \\
\hline Organic material (NION) & 330 & 3.31 & 12 & 3.28 \\
\hline Sand & 908 & 9.09 & 96 & 26.23 \\
\hline TOTAL & 9991 & 100 & 366 & 100 \\
\hline
\end{tabular}

The dietary category Crustacea was most representative, both in points (MP) and in occurrence (FO), followed by Osteichthyes and Mollusca, while the less representative categories were Macrophyta and Foraminiferida, with the remaining categories participating only moderately in the species' trophic spectrum (Table 2). In other species of the Callinectes genus, Crustacea also represented an important dietary source (Moncada \& Gómez, 1980; Haefner, 1990; Stoner \& 
Buchanan, 1990; Branco, 1996). Analyzing the dietary composition from a seasonal standpoint, variations wese observed throughout the year. In spring, the most significant prey in terms of IAi were Crustacea (0.695) and Osteichthyes (0.229), followed by Mollusca (0.030) and Polychaeta (0.029) in second place and the remaining prey classified as occasional (Figure 1). The Polychaeta contributed to the diet of the Crustacea Decapoda Brachyura, constituting a dominating group in unconsolidated substrates. Nonato et al. (1990), working with six species of Brachyura, found that Polychaeta was present in $25.3 \%$ of the analyzed stomachs of $C$. ornatus, represented by the Eunicea and Pectinariidae families. In the Itapocoroy inlet, the Polychaeta which was identified in stomachs belonged to the Polynoide family. According to Nonato et al. (1990), this group predominated on the diet of juvenile $C$. ornatus. In his study of the natural diet of $C$. danae in the Lagoa da Conceição, state of Santa Catarina, Brazil, Branco (1996) reported that the juveniles of this species cought prey which were little or with no mobility (the Polychaeta).

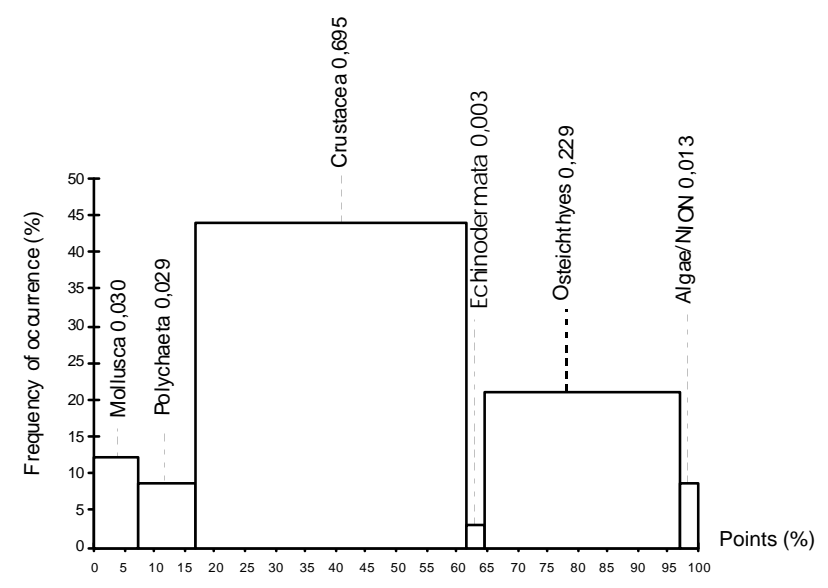

Figure 1 - C. ornatus. Frequence of occurrence (\%) and of points $(\%)$ of the dietary groups and their respective IAi in spring.

Similar findings were reported for the summer season, with Crustacea and Osteichthyes also representing the most important prey; however, Mollusca were also occasional prey (Figure 2).

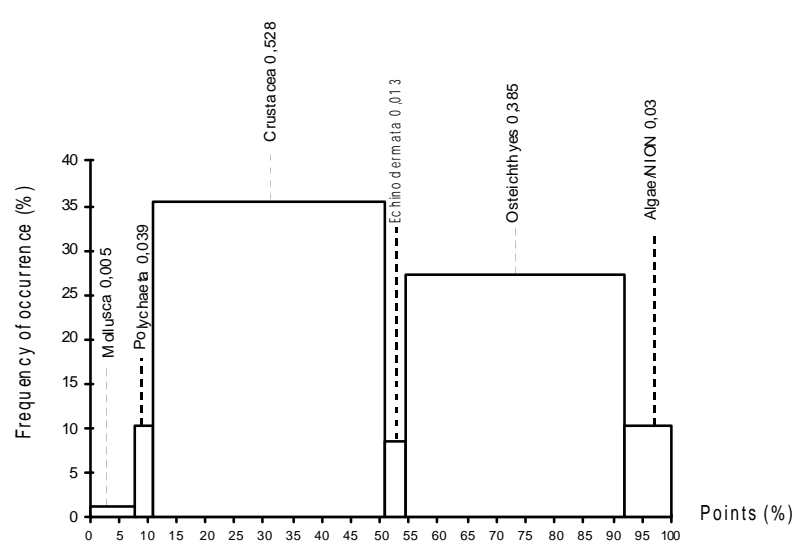

Figure 2 - C. ornatus. Frequency of occurrence (\%), and points $(\%)$, of the feeding groups and theirs respective IAi in summer.

Crustacea continued representing the most important diet in autumn (0.4224), although Mollusca, which were occasional in summer, took secondary place in the fall $(0.2878)$. This change was ascribed to the availability of this group in the environment (Figure 3). Autumn presented the greatest diversity of prey, represented by Mollusca Bivalve, Gastropoda and Loligonidae; Polychaeta, Bracyura, Callinectes genus, species of the Penaeidae family, Farfantepenaeus paulensis, Ophiuroide, Osteichthyes, algae and organic material; while the Penaeidae were the most representative prey among the Crustacea.

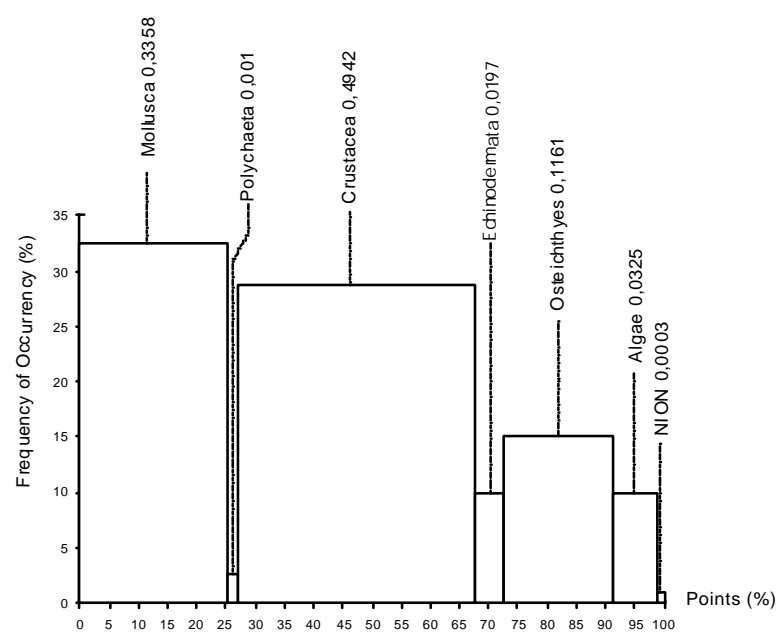

Figure 3 - C. ornatus. Frequency of occurrence (\%), and points $(\%)$, of the feeding groups and theirs respective IAi in fall. 
The diversity of prey was found to diminish in winter in comparison to autumn, with Crustacea representing the chief diet, followed by Mollusca and Osteichthyes (Figure 4). The dietary category of algae, though present in every season except winter, was found to be of secondary importance. Generally speaking, one can consider that the most preyed on categories were Crustacea, Osteichthyes and Mollusca. Crustacea, therefore, were present throughout the four seasons and represented the basis of the natural diet of $C$. ornatus, which was composed of Amphipods, Decapoda Penaeidae/Sergestidae, together with the species Farfantepenaeus paulensis and other species of the Penaeus genus that were not properly identified to the high degree of digestion, Acetes americanus, Portunidae in general and species of the Callinectes genus; Xanthidae, Brachyura, Anomura, Diogenidae with the species Dardanus insignis and Crustacea eggs (Figure 5; Table 2).

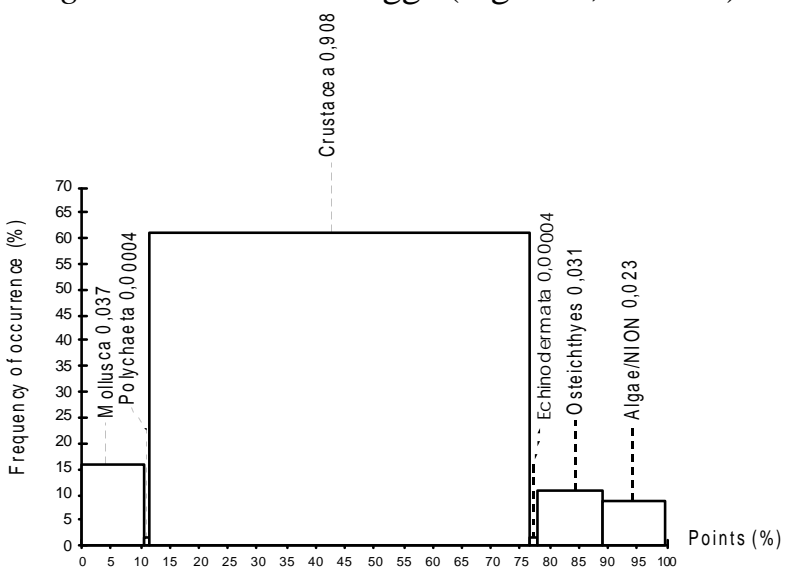

Figure 4 - C. ornatus. Frequency of occurrence (\%), and points (\%), of the feeding groups and theirs respective IAi in winter.

Callinectes ornatus presented a diversified trophic spectrum with a generalized feeding strategy and, therefore, a large niche, which was represented by its successful ingestion of animals of inferior trophic levels. Similar to C. danae (Branco, 1990), C. ornatus plays an important role in the transfer of energy of the ecosystem. C. ornatus can be considered an opportunistic predator of slowmoving macroinvertebrates. The presence or absence of any given trophic group in the diet of this species depends on the most recently visited; microhabitat as well as the availability of prey in the environment (Haefner, 1990; Branco, 1996). This predatory behavior was confirmed by Lipcius \& Hines (1986) for Decapoda, whose behavior was a possible delimiting factor of the abundance and distribution of prey in unconsolidated substrates.

\section{RESUMO}

Alimentação natural de Callinectes ornatus Ordway, 1863 (Decapoda, Portunidae) na Armação do Itapocoroy, Penha, SC - Brasil. No período de janeiro a dezembro de 1995, foram coletados 332 indivíduos de Callinectes ornatus, procedentes da Armação do Itapocoroy (Penha, SC). Foi estudada a alimentação natural da espécie e as variações sazonais da dieta.

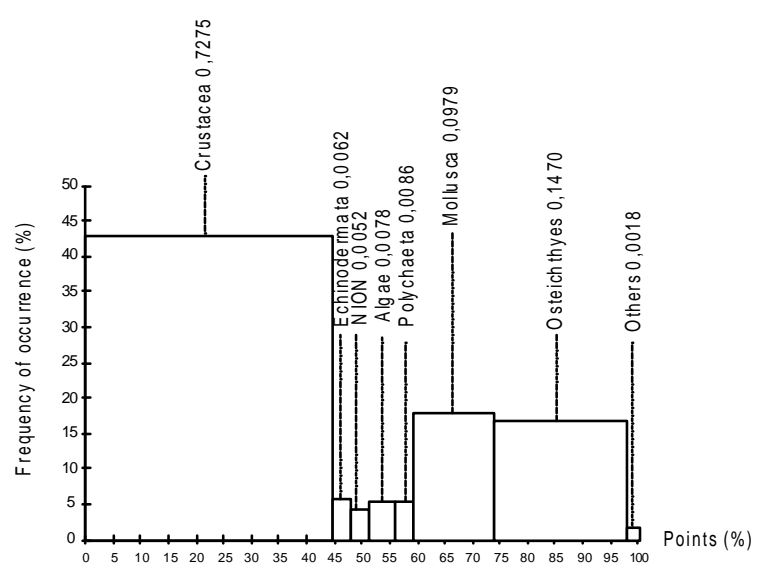

Figure 5 - C. ornatus. Frequency of occurrence (\%), and points (\%), of the feeding groups and theirs respective IAi in general.

Os resultados mostram um espectro trófico diversificado, com estratégia alimentar generalista, sendo Algas, Macrófitas, Foraminiferida, Mollusca, Polychaeta, Crustacea, Echinodermata, Osteichthyes e matéria orgânica não identificada, os grupos que compõem sua dieta.

\section{REFERENCES}

Amaral, A. C. Z. and Nonato, E. F. (1981), Anelídeos poliquetas da costa brasileira; características $e$ chaves para as famílias; glossário. Brasília, CNPq. v. $1 / 247 \mathrm{pp}$.

Amaral, A. C. Z. and Nonato, E. F. (1982), Anelídeos poliquetas da costa brasileira: Aphroditidae e Polynoidae. Brasília, CNPq, vol. 3, 46pp.

Barnes, R. D. (1984), Zoologia dos Invertebrados. São Paulo, Livraria Roca. 1179pp. 
Blunoon, J. A. and Kennedy, V. S. (1982), Mechanical and behavioral aspects of blue crab Callinectes sapidus (Rathbun), predation on Chesapeake Bay bivalves. Journal Experimental Marine Biology Ecology, 65, 47-65.

Branco, J. O. (1996), Variações sazonais e ontogênicas na dieta natural de Callinectes danae Smith, 1869 (Decapoda, Portunidae) na Lagoa da Conceição, Florianópolis, SC. Arquivos de Biologia $e$ Tecnologia, 39(4), 999-1012.

Branco, J. O. and Lunardon-Branco, M. J. (1993a), Aspectos da biologia de Callinectes ornatus Ordway, 1863 (Decapoda, Portunidae) na região de Matinhos, Paraná, Brasil. Arquivos de Biologia e Tecnologia, 36(3), 489-496.

Branco, J. O. and Lunardon-Branco, M. J. (1993b), Crescimento e tamanho de primeira maturação em Callinectes ornatus Ordway, 1863 (Decapoda, Portunidae), na região de Matinhos, Paraná, Brasil. Arquivos de Biologia e Tecnologia, 36(3), 497-503.

Elner, R. W.; Beninger, P. G.; Linkletter, L. E. and Lanteingne, S. (1985), Guide to indicator fragments of principal prey taxa in the stomachs of two common Atlantic crab species: Cancer borealis Stimpson, 1859 and Cancer irroratus Say, 1817. Can. Tech. Rept. Fish. Aquat. Sci., (1403), 1-120.

Gore, R. H. (1977), A field character for rapid identification of the swimming crabs Callinectes ornatus Ordway, 1863 and C. similis Williams, 1966 (Brachyura: Portunidae), Northeast Gulf Science. 1, 119-123.

Haefner, P. A. Jr. (1990), Natural diet of Callinectes ornatus (Brachyura : Portunidae) in Bermuda. Journal of Crustacean Biology, 10(2), 236-246.

Hynes, H. B. N. (1950), The food of fresh-water sticklebacks (Gasterosteus aculeatus and Pygosteus pungitius) with a review of method used in studies of the food fishes. Journal Animal Ecology, 19(1), 36-51.

Kawakami, E. and Vazzoler, G. (1980), Método gráfico e estimativa de índice alimentar aplicado no estudo de alimentação de peixes. Boletim do Instituto Oceanográfico, São Paulo, 29(2), 205-207.

Lipcius, R. N. and Hines, A. H. (1986), Variable functional responses of a marine predator in dissimilar homogeneous microhabitats. Ecology, 67(5), 1361-1371.

Ludwig, J. A. and Reynolds, J. F. (1988), Statistical ecology: a primer on methods and computing. John Wiley \& Sons, Inc. 338pp.

Melo, G. A. M. (1996), Manual de identificação dos Brachyura (Caranguejos e Siris) do litoral brasileiro. Editora Plêiade FAPESP. 604pp.
Moncada, F. G. and Gómez, O. (1980), Algunos aspectos biológicos de tres especies del género Callinectes (Crustacea, Decapoda), Revista Cubana de Investigaciones Pesqueras, 5(4), 1-35.

Nonato, E F.; Peti, M. A. V. and Paiva, P. C. (1990), Contribuição dos anelídeos poliquetas na dieta de crustáceos decápodos braquiúros na região de Ubatuba. In: Simpósio de ecossistema da costa sul e sudeste brasileira. Águas de Lindóia, ACIESP. 71(1), 24-234.

Nonato, E. F. and Amaral, A. C. Z. (1979), Anelídeos Poliquetas. Chaves para famílias e gêneros. São Paulo. 78pp.

Norse, E. A. (1978), An experimental gradient analysis: hyposalinity as an "upstress" distributional determinant for Caribbean Portunid crabs. Biological Bulletin, 155, 586-598.

Paul, R. R. G. (1982), Abundance, breeding and growth of Callinectes arcuatus. Ordway and $C$. toxotes Ordway (Decapoda, Brachyura, Portunidae) in a lagoon system on the Mexican Pacific Coast. Estuarine and Coastal Shelf Science, 14, 13-20.

Rios, E. C. (1975), Braziliam Marine Mollusks Iconography. Fundação Universidade de Rio Grande. 1328 pp.

Stoner, A. W. and Buchanan, B. A. (1990), Ontogeny and overlap in the diets of four tropical Callinectes species. Bulletin Marine Science., 46(1), 3-12.

Taissoun, E. N. (1969), Las especies de cangrejos del genero "Callinectes" (Brachyura) en el Golfo de Venezuela y Lago Maracaibo. Bolm. Cent. Invest. Biol., 2, 1-112.

Williams, A. B. (1974), The swimming crabs of the genus Callinectes (Decapoda : Portunidae), Fishery. Bulletin., 72(3), 685-798.

Williams, M. J. (1981), Methods for analysis of natural diet in Portunidae crabs (Crustacea : Decapoda : Portunidae), Journal Experimental Marine Biology Ecology, 52, 103-113.

Williams, M. J. (1982), Natural food and feeding in the commercial sand crab Portunus pelagicus Linnaeus, 1766 (Crustacea : Decapoda : Portunidae) in Moreton Bay, Queenland Journal Experimental Marine Biology Ecology, 59, 165-176.

Received: September 06, 2000; Revised: January 03, 2000; Accepted: April 26, 2001. 